LA-10628-MS

UC-25

lssued: February 1986

LA--10628-MS

DE86 007580

\title{
Liquid Plutonium Reaction with Titanium
}

\author{
S. Dale Soderquist \\ Kaye A. Johnson
}

\section{DISCLAIMER}

This report was prepared as an account of work sponsored by an agency of the United States Government. Neither the United States Government nor any agency thereof, nor any of their employees, makes any warranty, express or implied, or assumes any legal liability or responsibility for the accuracy, completeness, or usefulness of any information, apparatus, product, or process disclosed, or represents that its use would not infringe privately owned rights. Reference herein to any specific commercial produch, process, or service by trade name, tradernark, manufacturer, or otherwise does not necessarily constitute or imply its endorsement, recommendation, or favoring by the United States Gnvernment or any agency thereof. The views and opinions of authors expressed herein do not necessarily state or reflect those of the United States Government or any agency thereof. 


\title{
LIOUID PLUTONIUM REACTION WITH TITANIUM
}

by

S. Dale Soderquist, Kaye A. Johnson

\begin{abstract}
High purity plutonium penetrated into commercially pure titanium at an average rate of 0.006 inches per minuce during six minutes between $970^{\circ} \mathrm{C}$ and $1050^{\circ} \mathrm{C}$, under partial vacuum. It is belleved that, due to the constrained geometry of the titanium cup and the loss of some olutonium due to penetration through an upper wall of the cup, the plutonium-titanIum reaction rate was slowed and penetration stopped at 0.038 inches into the titanium. Conservative calculations based on the plutonium-titanium equilibrium phase diagram at $1050^{\circ} \mathrm{C}$ show that plutonfum could have penetrated into the titanium cup at least 0.10 inches. Therefore, equilibrium conditions were not approached after the six minute test. A less-constrained titanium cup design with a lower titanium surface to plutonium volume ratio is being considered for further plutonium-titanium reaction studies.
\end{abstract}

\section{INTRODUCTION}

The orfginal purpose of this study was to obtain reaction-rate data, at various temperatures near $1000^{\circ} \mathrm{C}$, of plutonfum penetration into containers made of titanium and titanium- $6 \%$ aluminum $-4 \%$ vanadium. A preliminary test was done with high purity plutonium in a commerclally pure titanium cup, and the reaction rate was rapid. This study has since been broadened in scope to include other metals and coatings for containment of $\mathrm{Pu}$ at $1100^{\circ} \mathrm{C}$. Also, based on the preliminary test, the containment cup configuration has been changed.

\section{IT. REPORT}

The preliminary experimental test set-up included a commerclally pure titanium cup machined to the dimensions shown in Fig. 1 (see Fig. 2 for microstructure). The titanium cup, nearly filled with plutonium in the center well and thermocouple inserted in the side well, was surrounded by a graphite susceptor/holding vessel, and heated inductively. The assembly was held six minutes between $970^{\circ} \mathrm{C}$ and $1050^{\circ} \mathrm{C}$ under partial vacuum. The plutonium penetrated through the upper titanium wall into the thermocouple well and through the outer wall, allowing some of the plutonium to leak out of the cup (Fig. 3 ). Also, a small part of the stainless steel sheathed thermocouple reacted with 
the titanium (and plutonium) in the thermocouple well, possibly aiding plutonlum penetration of the outer titanium wail. However, this would not have affected plutonium penetration into the bottom of the center well since the plutonfum-ticanium-stainless liquid flowed away from the center well. In addition, since plutonium melts first at $640^{\circ} \mathrm{C}$ and filled the bottom of the center titanium well, reaction of plutonium into the bottom of the titanium cup would inftiate before titanium-nickel eutectic melts at $955^{\circ} \mathrm{C}$. The plutonium titanium interface is shown after cooling at the bottom of the center well (Fig. 4).

Penetration measurements into the bottom of the center well show a reaction depth of 0.038 inches which averages 0.006 inches per minute penetration rate for six minutes between $970^{\circ} \mathrm{C}$ and $1050^{\circ} \mathrm{C}$. However, it is believed that due to the constrained geometry of the original experimental titanium cup, and the loss of some plutonium by leakage, the reaction was prematurely slowed. With a new hemispherical cup design, more liquid plutonium per unit surface area of ti.tanium will be available which should increase reaction rate and penetration for a given temperature and time.

Conservative penetration calculations based on equilibrium solubility of plutonium in titanium at $1050^{\circ} \mathrm{C}$ (Fig. 5) ${ }^{1}$ show that plutonium could have penetrated into the titanium cup at least $0.10^{\prime \prime}$ with the geometry used. Therefore, equilibrium conditions were not approached during this test. The calculations were conservative because it was assumed that the amount of liquid plutonium in the titanium cup at the start of the experiment was at the final liquid level after some pluconfum had leaked out, as measured from Fig. 2. Also, because of the steep solidus line slope in the plutonium-titanium phase diagram (Fig. 5), a change in temperature will not change solubility significantly, only kinetics. That is, with fixed amount of plutonium, the achievable depth of penetration will not change significantly with temperature varlations of $100^{\circ} \mathrm{C}$ or so near $1100^{\circ} \mathrm{C}$. However, the rate of penetration toward equilibrium conditfons will increase rapidly with a temperature rise of $100^{\circ} \mathrm{C}$.

Further tests of plutonium penetration into various materials at $1100^{\circ} \mathrm{C}$ are intended with a hemispherical cup design, and will be the subject of future reports.

\section{CONCLUSIONS}

1. Equilibrium penetration of plutonium into titanium was not reached in this experiment after six minutes between $970^{\circ} \mathrm{C}$ and $1050^{\circ} \mathrm{C}$.

2. Reaction rate of liquid plutonium with titanium is rapid, even under partial vacuum conditions where a partially protective coating of titanium oxide is expected.

3. Very clean surfaces and a good vacuum will probably increase penetration rate of liquid plutonium into titanium over that reportcd here.

4. A less-constrained cup design with a lower titanium surface to plutonium volume ratio would increase plutonium penetration. 


\section{REFERENCE}

1. Ellinger, F. H., et al. "Constitution of Plutonium Alloys," Los Alamos Scientific Laboratory report LA-3870, P-115 (December 1968). 


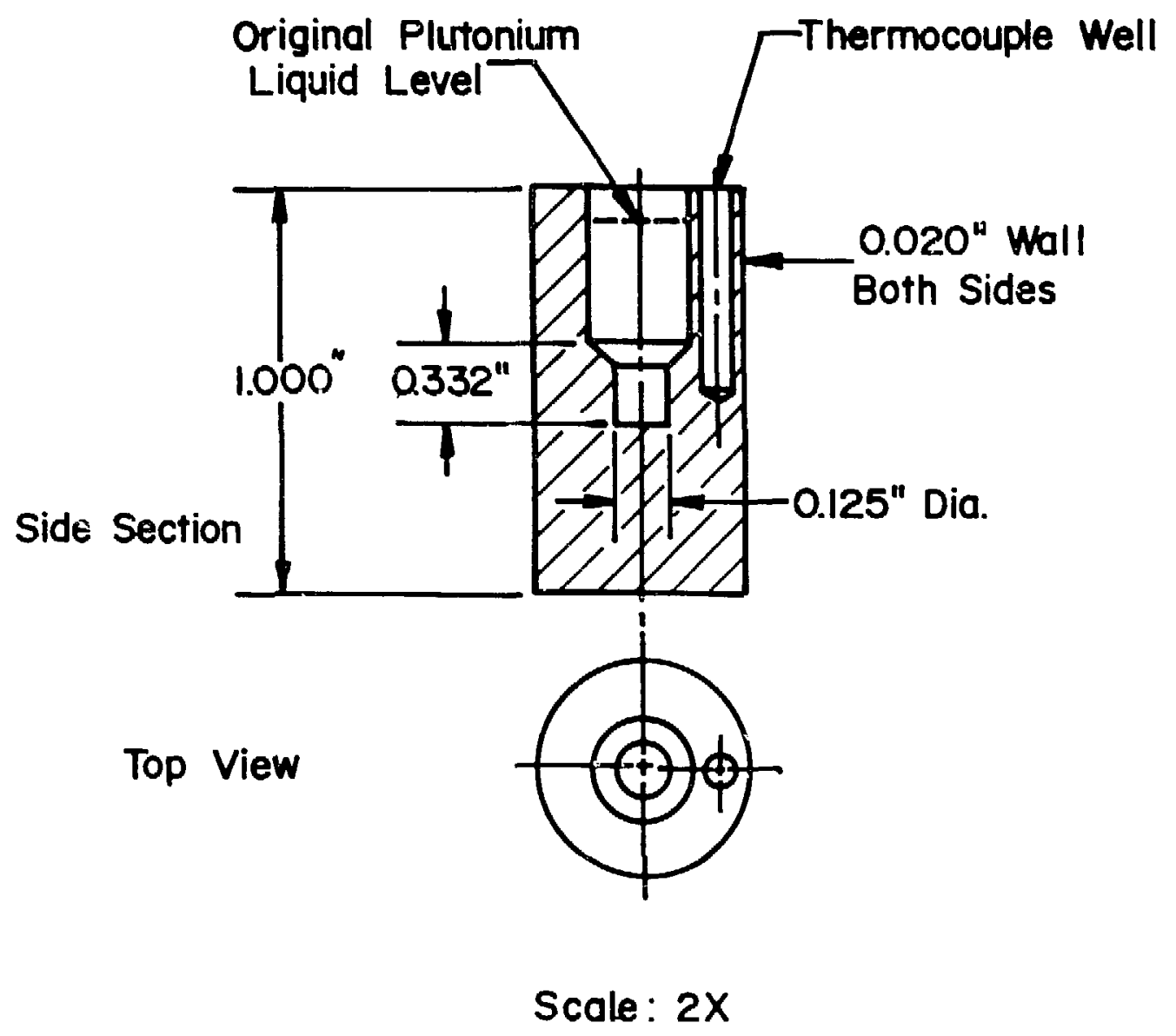

Fig. 1. Titanium Cup. 


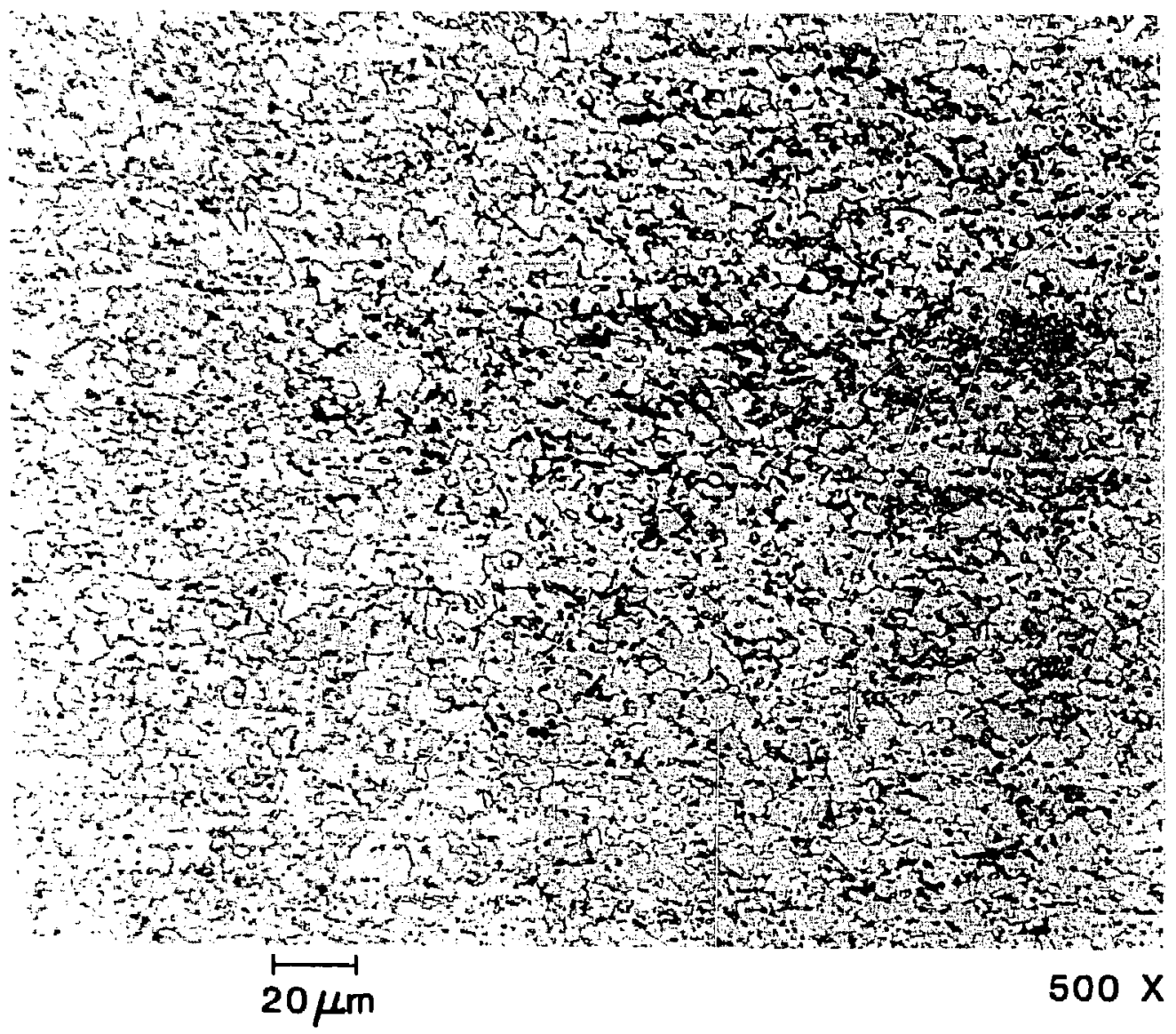

Fig. 2. Commerclally Pure Titantum Rod, Longltudinal Section. 


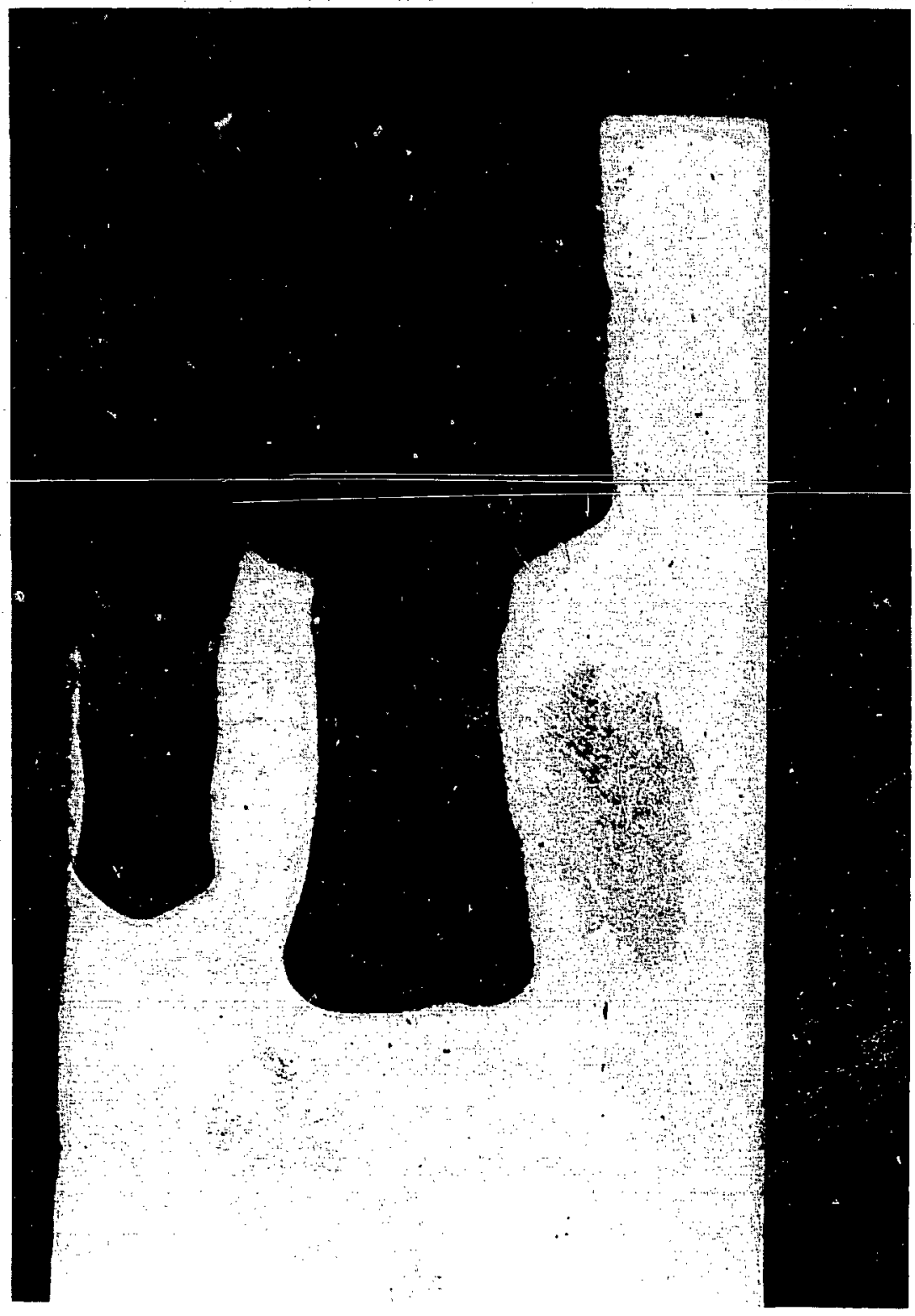

F1g. 3. Titanium Cup After Reaction with Liquid Plutonfum. 


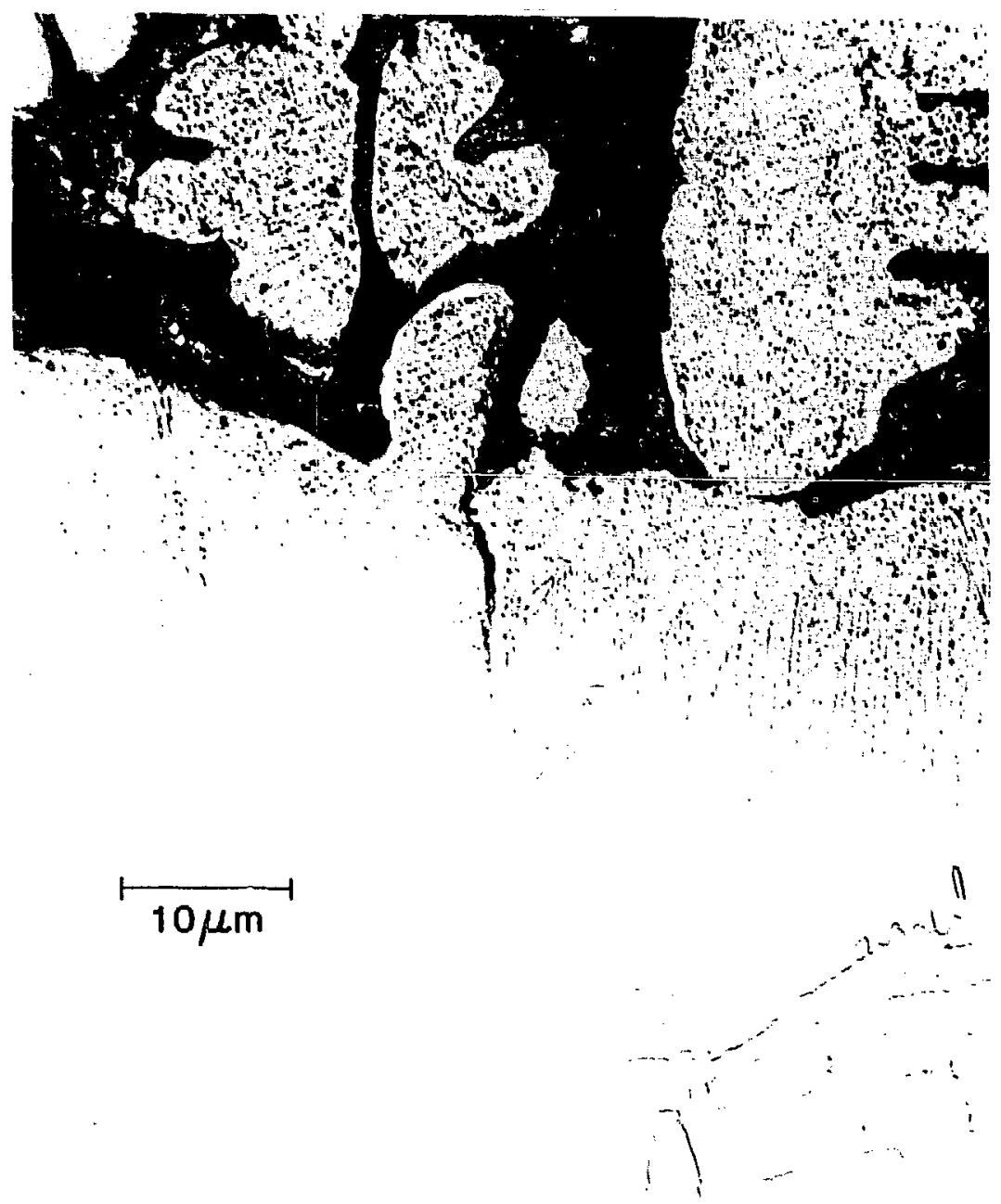

F1g. 4. Liquid Plutonium/Titanium Interface After Testing. 


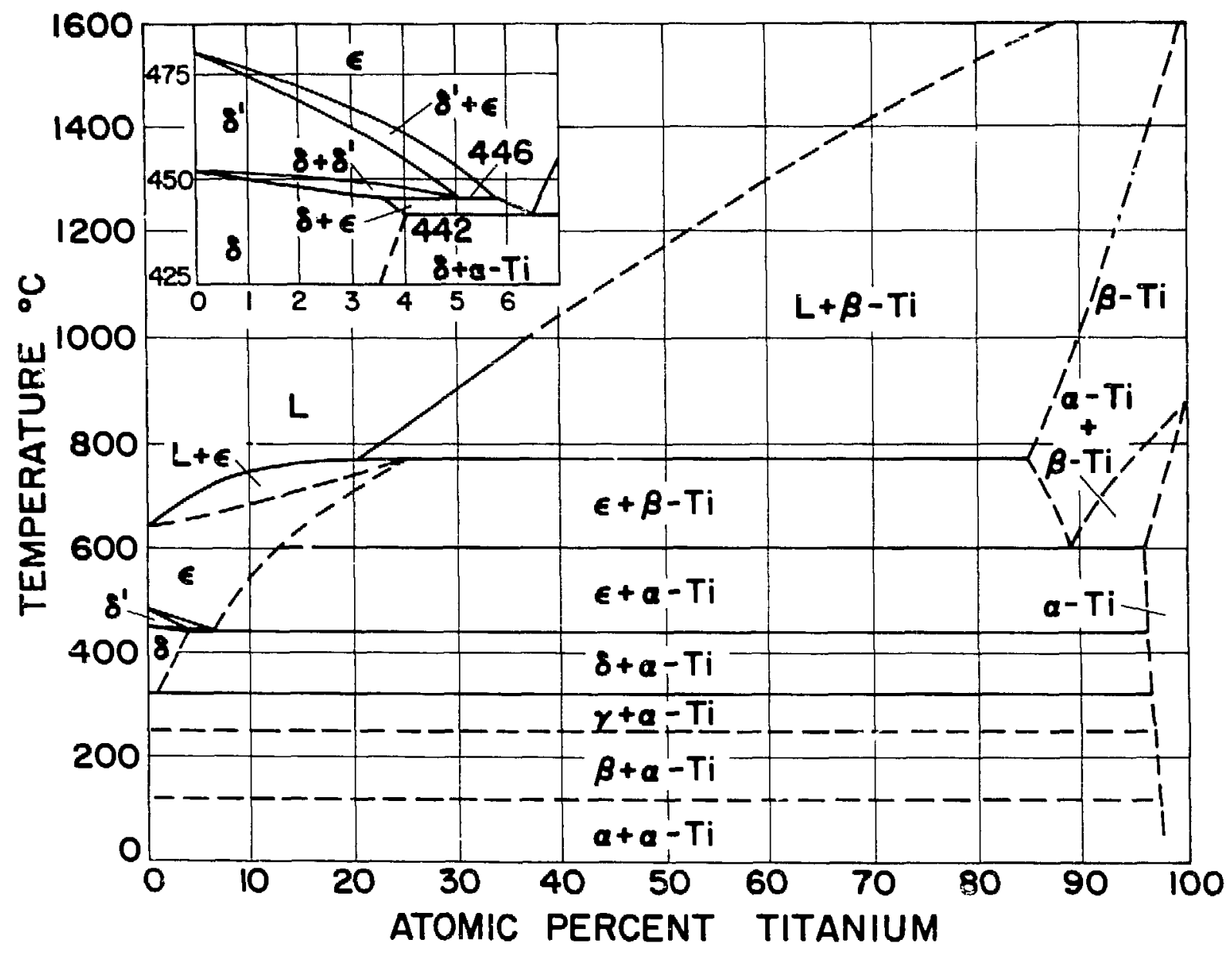

F1g. 5. Equilibrium Phase Diagram of PIutonium-Titanium. 